\title{
Studies of Sulfobromophthalein Sodium (BSP) Metabolism in Man. I. In Normal Subjects and Patients with Hepatic Disease *
}

\author{
Leslie J. Schoenfield, William T. Foulk, and Hugh R. Butt \\ (From the Section of Medicine and the Gastrointestinal Research Unit, Mayo Clinic and Mayo \\ Foundation, Rochester, Minn.)
}

\begin{abstract}
Although sulfobromophthalein sodium (BSP, Bromsulphalein) has been used extensively for testing hepatic function since its introduction by Rosenthal and White in 1925 (1), relatively little was learned regarding its transport and metabolism until recent years. Disappearance of BSP from the blood after intravenous administration of the dye involves a complicated process (2). It is effected by the interrelated functions of hepatic uptake, storage, conjugation, and biliary excretion, each of which may be influenced by such dynamic factors as blood circulation and protein availability (3). The precise role of extrahepatic metabolism (4) and the importance of the enterohepatic circulation (5) of BSP in the physiology of normal and of pathologic states have not yet been clearly established.
\end{abstract}

The rate of disappearance of BSP from the blood (fractional clearance or percentage disappearance rate, PDR) has been suggested as a more sensitive index of liver function than is the percentage of intravenously administered BSP retained after a specific time interval $(6,7)$. Barber-Riley, Goetzee, Richards, and Thomson (8) have shown that after a single intravenous dose of BSP, the disappearance curve can be expressed as two exponential terms from which the rate of transfer from plasma to liver and that from liver to bile may be calculated. The initial exponential portion of the disappearance curve for BSP is likely a reflection of the function of hepatic uptake, although extrahepatic and enterohepatic influences have not been entirely excluded.

In 1950 Bratuer and Pessotti (9) discovered that a metabolic transformation of most of the

* Submitted for publication December 23, 1963; accepted February 27, 1964.

This investigation was supported in part by research grant AM-06908 from the National Institutes of Health.
BSP administered intravenously occurs in the liver. Workers in other laboratories subsequently confirmed the presence of this chemically altered BSP (10-12). It has been generally agreed that conjugation of BSP occurs primarily with glutathione, although the amino acids, glycine, glutamic acid, and cysteine (the components of the peptide glutathione), may participate also. A recent suggestion has been that the measurement of BSP metabolites in the serum may serve to distinguish those situations in which the uptake or the conjugation of BSP is impaired from instances in which conjugation proceeds normally but "regurgitation" of the metabolites occurs (13).

The concepts of hepatic storage (14) and maximal biliary transport (transfer maximum, Tm) (15) have received support from recent studies utilizing continuous-infusion technics with simultaneous bile collections in dog and man $(16,17)$. With infusion of BSP at a rate calculated to maintain a steady level of BSP in the plasma, the quantity cleared by the liver during a given interval is assumed to be equal to the quantity of the substance injected into the blood during that same time. Combes, Wheeler, Childs, and Bradley (18) found that when a large priming dose of BSP was administered at the time that a constant infusion was started, the hepatic removal rate was much higher transiently than the $\mathrm{Tm}$. This suggests a rapid initial movement of BSP into a "storage compartment." Maintenance of the maximal rate of biliary excretion during a period of decreasing plasma concentration suggests a release of BSP from hepatic storage to the bile. Thus the indication is that BSP accumulates in liver cells in some fixed gradient with respect to plasma and is transferred into bile by a rate-limited transport system (19).

This report presents a profile of BSP trans- 
port and metabolism in normal individuals and in patients with hepatic disorders in whom measurements reflecting hepatic uptake, storage, conjugation, and biliary excretion of BSP have been obtained.

\section{Methods}

Subjects. Thirty-three individuals with several types of hepatic disease were studied, and 19 subjects free of hepatic disorders served as controls. The control group included some who had peptic ulcer or functional complaints and some who were healthy volunteers; none had clinical or laboratory evidence of liver disease. Of the patients with hepatic disease, 12 had portal or postnecrotic cirrhosis, 16 had hepatic obstruction (6 intrahepatic, including 2 with primary biliary cirrhosis and 4 with drug cholestasis, and 10 extrahepatic), two had hemochromatosis (with cirrhosis), one had hemosiderosis (without cirrhosis), and one had polycystic disease of the liver. Serial measurements were made in a patient as he convalesced from viral hepatitis. The diagnosis in each case was established by liver biopsy or at operation.

Procedures. Values for three parameters were determined in conjunction with a single intravenous injection of BSP: 1) BSP retention in serum at 60 or 120 minutes or both, 2) percentage of serum BSP that was conjugated, and 3) fractional clearance (PDR) as a reflection of hepatic uptake of BSP. Two days later. values for three others were measured with the use of a continuous infusion of BSP:4) maximal transport rate (Tm) for biliary excretion, 5) relative hepatic storage capacity (S), and 6) conjugated BSP in the serum. Each subject went without breakfast before the tests and lay comfortably on a bed during the tests.

Single injection of $B S P$. After a control blood specimen was taken, $5 \mathrm{mg}$ of BSP per $\mathrm{kg}$ of body weight was injected intravenously, emptying the syringe within 15 seconds. Blood samples were drawn from the opposite arm at 5-minute intervals during a period of 15 to 30 minutes, with separate sterile syringes and needles used for the pretest sample and each subsequent test sample. Additional samples were obtained 60 or 120 minutes or both after the injection of BSP for determination of the percentage of BSP retention. Optical density of serum specimens was determined at $580 \mathrm{~m} \mu$ in a Coleman spectrophotometer after alkalinization using the pretest sample as a blank. Although turbidity, hemolysis, and the like were rare, minor analytical errors might have been avoided if each sample had served as its own blank. Grossly hemolyzed or turbid serum specimens were discarded. Standard curves were prepared by addition of known amounts of BSP to pooled normal plasma and to jaundiced sera, and the BSP concentration in the sera tested was read from the standard curves. Waiting 15 minutes after alkalinization for decolorizing the bilirubin permitted accurate determination of the BSP concentration in jaundiced sera (16), The resultss were plotted on semilogarithmic graph paper, and the PDR was calculated from the BSP concentrations at 5,10 , and 15 minutes after the injection. In most instances, including those where hepatobiliary disease was involved, a straight line could be determined from a semilogarithmic plot of results from this 15-minute period. Beyond that period a straight line could not be determined often, and the PDR was found usually to decrease progressively with time.

Most serum specimens were submitted also to chromatographic analysis by the technic of Meltzer, Wheeler, and Cranston (12) for the determination of free and conjugated BSP using ascending paper chromatography with the solvent system $n$-butanol:glacial acetic acid (4:1, vol:vol) saturated with water. Three different compounds whose absorption spectra were identical with BSP were demonstrated chromatographically in most serum specimens. One had an $R_{f}$ of about 0.50 and was identical in chromatographic mobility with commercially available BSP. The other two compounds (BSP metabolites), having $R_{\mathfrak{f}}$ values of about 0.40 and 0.30 , were combined in these experiments to give a value for conjugated BSP. When known amounts of free BSP were added to the sera of 15 control subjects as a standard for paper chromatographic determination of BSP conjugates, $91.0 \%( \pm 4.1)$ was recovered in the final colorimetric determination. Duplicate determinations agreed within $8 \%$. The addition of BSP to serum specimens in vitro yielded only free BSP, whereas the metabolites of BSP were found in serum only after intravenous administration of the dye. When a colorimetrically determined amount of conjugated BSP obtained from a paper chromatogram was evaporated, dissolved in serum, and rechromatographed, about $85 \%$ of the conjugated BSP could be recovered.

Continuous infusion of BSP. The method of Wheeler, Meltzer, and Bradley (16) was used for the determination of $\mathrm{Tm}$ and $\mathrm{S}$. These investigators have shown that $\mathrm{Tm}$ for BSP may be estimated from observations on peripheral plasma concentrations during different rates of constant infusion without resort to bile collections, hepatic venous sampling, or measurements of hepatic blood flow.

After an initial blood sample had been obtained, BSP was infused intravenously at a carefully controlled constant drop rate for 1 hour. For individuals without hepatic disease this rate was about $0.30 \mathrm{mg}$ per minute per $\mathrm{kg}$ body weight, whereas for those with hepatic disease the initial infusion rate was decreased to 0.15 mg per minute per $\mathrm{kg}$ so as not to produce excessively high levels of serum BSP during the course of the infusions. There were no untoward effects of the BSP administrations reported by any of the patients or observed. The infusion rates were changed for both groups to approximately 0.3 of the initial rate during the second hour and 0.6 during the third hour. The precise rates of infusion were calculated from measurements of BSP concentration and volume for the hour of infusion. During the last 30 minutes of each hour 
of infusion, four venous samples were drawn at 10minute intervals from an indwelling needle in the arm opposite that used for the infusion. Blood samples were obtained rapidly and with a minimum of agitation in order to avoid visible hemolysis. BSP concentration was determined in all samples, and the percentage existing as conjugated dye was determined in most of the blood samples as described.

The theoretical hepatic removal rate $(R)$ was calculated for each hour of infusion according to the formula developed by Wheeler, Epstein, Robinson, and Snell (19): $R=I \pm P V(\Delta P / \Delta T)$, where $I$ is infusion rate (milligrams per minute), $\mathrm{PV}$ is plasma volume (milliliters per 100$)$, and $\Delta \mathrm{P} / \Delta \mathrm{T}$ is the rate of change of plasma concentration (milligrams per 100 milliliters per minute). Plasma volume was measured by use of I131-labeled human serum albumin. The three values for $R$ obtained during the three infusion periods were plotted as ordinates against the corresponding values of $\Delta \mathrm{P} / \Delta \mathrm{T}$ as abscissas, and the best-fitting straight line through the three points was determined by the method of least squares. The theoretical $\mathrm{Tm}$ is then equal to the value of $\mathrm{R}$ for which $\Delta \mathrm{P} / \Delta \mathrm{T}=0$, and $\mathrm{S}$ is equal to the slope of the line.

\section{Results}

$\mathrm{BSP}$ retention in the serum at 60 minutes after a single intravenous injection of $5 \mathrm{mg}$ per $\mathrm{kg}$ body weight in subjects free of hepatic disease is less than $5 \%$, and measurement of BSP conjugates in the serum by paper chromatography is technically impractical when retention is that slight. Accordingly, among the control group this measurement could be made in only 4 subjects. Their 60-minute BSP retention ranged from 6 to $10 \%$, and they had no other clinical or laboratory evidence of hepatic disease. In these instances, only trace amounts of conjugated BSP were found in the serum. No significant amount of conjugate was found in any of the serum samples obtained at 5, 10, and 15 minutes after a single intravenous injection of BSP in any subject, with or without hepatobiliary disease. Specimens obtained at 20,25 , or 30 minutes, however, did contain conjugated BSP.

The determination of $\mathrm{Tm}$ and $\mathrm{S}$ by the constant infusion technic is illustrated in Figure $1 a$ and $b$, which constrasts the results obtained from a subject free of hepatic disease with those from a patient with extrahepatic biliary obstruction. The ranges of serum BSP concentration during the course of the different infusion rates used for subjects with and without hepatic disease were comparable. The relationship between serum concentration and time during the second half hour of each infusion period was linear. Likewise, a linear relationship was demonstrated between the hepatic removal rate and the change in plasma concentration with time during each of the three infusion periods.

Table I shows the values obtained for PDR, $\mathrm{Tm}$, and $\mathrm{S}$ in 19 subjects without hepatic disorder. In addition, the PDR was determined in 14 other subjects without hepatic disorder whose data are not included in the Table. There was no significant regression for $\mathrm{S}$ or $\mathrm{Tm}$ with age or weight, although $\mathrm{Tm}$ tended slightly to decrease with age and to increase with weight. Although the mean $\mathrm{Tm}$ value for women $(7.6 \mathrm{mg}$ per minute) was less than that for men $(8.7 \mathrm{mg}$ per minute), the difference between these means was not statistically significant, nor was the difference between the corresponding means for $\mathrm{S}$. For the subjects without hepatic disease, the 95\% confidence limits (mean values \pm 2.1 times the SD) for each parameter were as follows: PDR, $11.9 \pm 2.6 \%$ per minute; $\mathrm{Tm}, 8.2 \pm 2.9 \mathrm{mg}$ per minute; and S, $60.6 \pm 27.7 \mathrm{mg}$ per $\mathrm{mg}$ per $100 \mathrm{ml}$ plasma. Repeat tests performed in the same individual without hepatic disease at intervals of 1 week to 1 month showed less variation in the value for $\mathrm{Tm}$ than for $\mathrm{S}$, although both parameters were rather well reproduced. Also shown in this Table is the ratio of $\mathrm{S}$ to $\mathrm{Tm}$ with $95 \%$ confidence limits of $7: 5 \pm 3.8$.

Tables II and III summarize the data for BSP metabolism and transport in various hepatic disorders. No significant differences were noted between the mean values for patients with extrahepatic obstruction and those for patients with intrahepatic obstruction, and therefore these groups were combined. The apparent differences that were noted between the groups were not dependent upon the serum bilirubin levels. The retention of BSP in serum 60 minutes after a single intravenous injection of the dye was greater than retention at 120 minutes in both subgroups, although with biliary obstruction the retention at 120 minutes was significantly less than with cirrhosis $(p<0.01)$. The percentage of total serum BSP conjugated at 60 minutes was significantly less in the cirrhotic group than in the group with biliary obstruction $(p<0.001)$. At 120 minutes, 
when most of the serum BSP in all patients with hepatic disorders was in conjugated form, the mean percentages for the two subgroups were similar. Values of PDR, Tm, and S in the cirrhotic subgroup and the group with biliary obstruction were lower than those in the group free of hepatic disease. The higher values for the ratio $\mathrm{S} / \mathrm{Tm}$ occurred with biliary obstruction $(\mathrm{p}<$ 0.05 ), suggesting a relatively greater decrease of $\mathrm{T} \mathrm{m}$ than $\mathrm{S}$ in these individuals. Low values for $\mathrm{S} / \mathrm{Tm}$ occurred in both subgroups, however.

Two of 4 patients with intrahepatic cholestasis due to drugs had normal $\mathrm{S}$ with decreased biliary excretion. Two patients with hemochromatosis had normal values for $\mathrm{S}$ and $\mathrm{Tm}$ and normal 60 minute retention, but PDR was moderately decreased. In the subjects with polycystic liver and hemosiderosis, all parameters had values that were essentially normal.

The percentage of conjugated BSP in the total serum BSP during the course of continuous infusion of the dye at three different rates is shown in Table IV. Most of the blood specimens obtained at 30 minutes during the first infusion pe- riod did not contain $\mathrm{BSP}$ conjugate. When the mean values for percentage of BSP present in conjugated form were plotted against the time for continuous infusion of dye (Figure 2), there were significant positive regressions of the former on the latter for the group without hepatic disease and for the subgroups with cirrhosis and with biliary obstruction. The correlation coefficients were $0.9983(p<0.001), 0.9694(p<0.01)$, and $0.9814(\mathrm{p}<0.001)$, and the linear regression equations were $y=-11.87+0.3638(x), y=$ $-4.13+0.3576(x)$, and $y=-8.26+0.5152$ $(x)$, respectively. The slope of the regression line (b) was essentially the same in the group without hepatic disease and the cirrhotic subgroup but significantly greater in the subgroup with biliary obstruction. The quadratic components were not statistically significant.

Table V shows values for parameters of BSP transport and metabolism obtained at intervals during a 6-week period from a patient with viral hepatitis. All values were abnormal at the initial testing. Six weeks later the patient apparently had recovered from this illness, as suggested

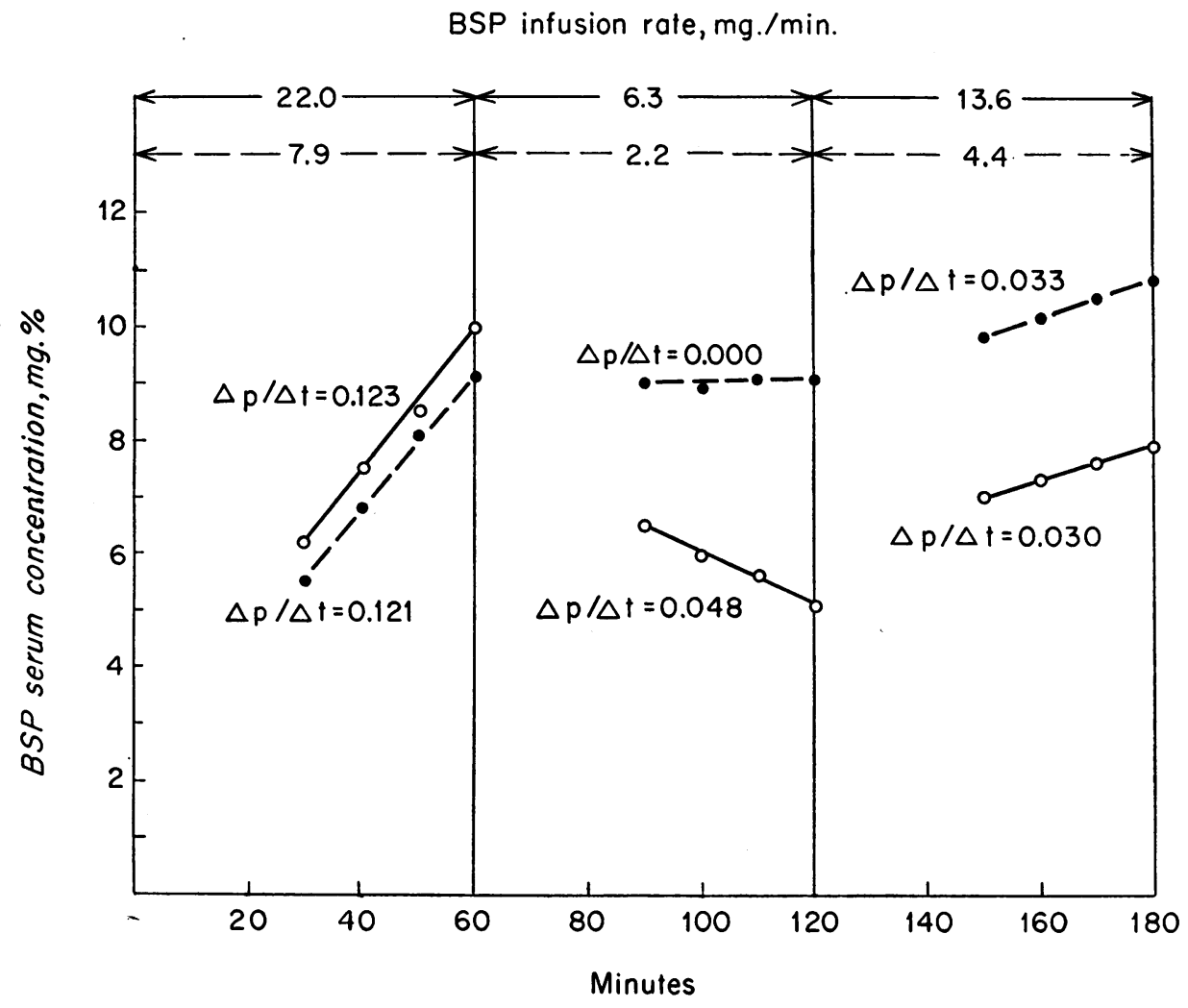

Fig. 1.-Continued on page 1413. 


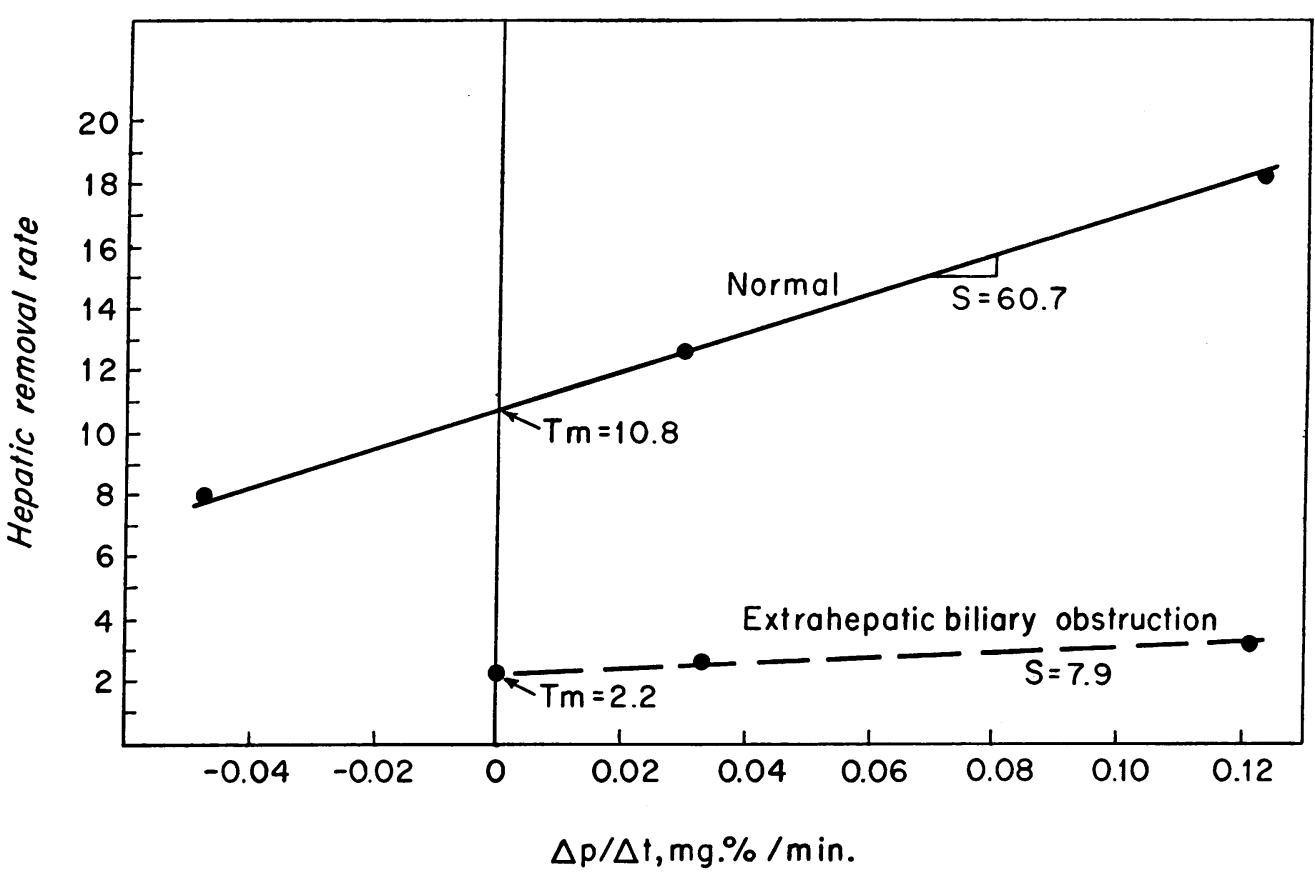

Fig. 1. Estimation of TM AND $S$ For BSP in a SUbJect without hepatic disorder (-) AND IN A PATIENT WITH EXTRAHEPATIC OBSTRUCTION (---) BY THE CONTINUOUS INFUSION TECHNIC. a) Change in serum concentration with time $(\Delta \mathrm{p} / \Delta \mathrm{t})$ during the secand half hour of each indicated infusion period. $b$ ) Determination of theoretical $\mathrm{Tm}$ and $\mathrm{S}$ by plotting $R$ (hepatic removal rate) against the corresponding values of $\Delta \mathrm{p} / \Delta \mathrm{t}$ for each infusion rate (I). Plasma volume was $3,024 \mathrm{ml}$ for normal subjects and $3,598 \mathrm{ml}$ for the patient. Tm equals value of $\mathrm{R}$ for which $\Delta \mathrm{p} / \Delta \mathrm{t}=0 ; \mathrm{S}$ is slope of line.

by clinical examination and by the conventional tests of liver function. At this time only the values for $\mathrm{Tm}$ and $\mathrm{S} / \mathrm{Tm}$ remained abnormal; all others had returned to normal, including that for conjugation of BSP during continuous infusion.

\section{Discussion}

Carbone, Grodsky, and Hjelte (20) found a significant difference between patients with hepatocellular disease and those with biliary obstruction in the percentage of retained serum BSP that was conjugated 45 minutes after a single intravenous injection of the dye. The proportions of conjugated BSP found in our patients at 60 minutes are similar to those found by these investigators at 45 minutes.

Higgins, Foulk, and Bollman (21) concluded that chromatography of dye extracted from the serum of jaundiced patients after a single injection of BSP yielded "suggestive results which warrant further investigation." Our findings suggest that comparisons between the 60 - and 120 minute percentages of retention after a single injection of BSP in conjunction with the proportion of retained BSP that is conjugated at 60 minutes may further help to elaborate the pathophysiologic mechanisms involved.

The mean value of serum BSP retention at 60 minutes after a single injection was about the same in the subgroups with biliary obstruction (37\%) as in the cirrhotic subgroup $(38 \%)$. At the same time, the difference between the mean percentage of conjugated BSP in the biliary-obstruction subgroups (42) and that in the cirrhotic subgroup (20) suggests a greater reflux or regurgitation of conjugated BSP with obstruction. The retained total BSP at 60 minutes also may result from defects in hepatic uptake, or in storage or conjugation or both, or perhaps from a reflux of free BSP, although these data did not delineate the degree of these mechanisms. The greater retention found at 120 minutes in the subgroups 
TABLE I

Parameters of BSP transport and metabolism in subjects without hepatic disorder

\begin{tabular}{|c|c|c|c|c|c|c|}
\hline Age & Sex & Weight & $\begin{array}{l}\text { Fractional } \\
\text { clearance } \\
\text { (PDR) }\end{array}$ & $\begin{array}{c}\text { Maximal } \\
\text { biliary } \\
\text { excretion } \\
(\mathrm{Tm})\end{array}$ & $\begin{array}{l}\text { Relative storage } \\
\text { capacity (S) }\end{array}$ & $\mathrm{S} / \mathrm{Tm}$ \\
\hline & & $\mathrm{kg}$ & $\% /$ minute & $m g / m i n u t e$ & $\mathrm{mg} / \mathrm{mg} / 100 \mathrm{ml}$ plasma & \\
\hline 46 & $M$ & 87 & & 10.6 & 71.8 & 6.8 \\
\hline 51 & M & 86 & & 9.8 & 66.7 & 6.8 \\
\hline 31 & $\mathbf{M}$ & 80 & 10.5 & 10.8 & 60.7 & 5.6 \\
\hline 64 & $\mathbf{M}$ & 72 & 14.7 & 7.5 & 76.2 & 10.2 \\
\hline 63 & $\mathrm{M}$ & 60 & 11.2 & 6.8 & 39.3 & 5.8 \\
\hline 64 & M & 66 & 10.5 & 7.2 & 45.2 & 6.3 \\
\hline \multirow[t]{2}{*}{43} & $\mathrm{M}^{*}$ & 74 & 10.7 & 9.5 & 82.0 & 8.6 \\
\hline & & & & 9.4 & 76.4 & 8.1 \\
\hline \multirow[t]{2}{*}{30} & $\mathbf{M}^{*}$ & 68 & 11.6 & 9.2 & 72.8 & 7.9 \\
\hline & & & & $\begin{array}{l}8.8 \\
80\end{array}$ & $\begin{array}{l}71.0 \\
44.8\end{array}$ & $\begin{array}{l}8.1 \\
5.6\end{array}$ \\
\hline \multirow[t]{2}{*}{$\begin{array}{l}66 \\
42\end{array}$} & $\begin{array}{l}\mathbf{M}^{*} \\
\mathbf{M}^{*}\end{array}$ & $\begin{array}{l}82 \\
65\end{array}$ & 10.7 & $\begin{array}{l}8.0 \\
7.7\end{array}$ & $\begin{array}{l}44.8 \\
54.3\end{array}$ & $\begin{array}{l}5.6 \\
7.1\end{array}$ \\
\hline & & & & 8.0 & 42.8 & 5.4 \\
\hline \multirow{2}{*}{$\begin{array}{l}40 \\
47\end{array}$} & $\mathrm{~F}$ & 62 & 14.4 & 9.6 & 56.3 & 5.9 \\
\hline & $\mathrm{F}$ & 74 & 13.8 & 8.5 & 44.6 & 5.3 \\
\hline \multirow{2}{*}{$\begin{array}{l}73 \\
25\end{array}$} & $\mathrm{~F}$ & 75 & 10.2 & 8.6 & 65.1 & 7.6 \\
\hline & $\mathrm{F}$ & 46 & 12.4 & 6.7 & 75.5 & 11.3 \\
\hline \multirow{2}{*}{$\begin{array}{l}49 \\
58\end{array}$} & $\mathrm{~F}$ & 30 & 11.2 & 6.8 & 48.6 & 7.2 \\
\hline & $\mathrm{F}$ & 43 & 10.8 & 6.6 & 56.9 & 8.6 \\
\hline \multirow{2}{*}{44} & $\mathrm{~F}$ & 55 & 11.4 & 7.9 & 54.6 & 6.9 \\
\hline & $\mathrm{F}$ & 55 & 12.4 & 7.4 & 80.7 & 10.9 \\
\hline \multirow[t]{2}{*}{63} & $\mathrm{~F}^{*}$ & 55 & & 6.5 & 54.6 & 8.4 \\
\hline & & & & 6.8 & 40.8 & 6.0 \\
\hline \multicolumn{2}{|c|}{ Mean \pm 2.1} & & $11.9 \pm 2.6 \ddagger$ & $8.2 \pm 2.9$ & $60.6 \pm 27.7$ & $7.5 \pm 3.8$ \\
\hline
\end{tabular}

* The second of repeat determination is not included in the mean.

$\dagger$ Indicates $95 \%$ confidence limits.

$\ddagger$ Calculated from determinations in 29 subjects without hepatic disorders.

with biliary obstruction indicated that, during this time interval (60 to 120 minutes), the clearance of BSP from the blood of the cirrhotic subgroup proceeded at a faster rate than it did in the obstructed group or that there was less regurgitation in the cirrhotic subgroup. That the sera from individuals of both subgroups at 120 minutes contained similar proportions of conjugated BSP suggested that the function of time was of importance in BSP conjugation.

TABLE II

Serum retention of $B S P$ in hepatic disorders

\begin{tabular}{lccccc}
\hline & \multicolumn{2}{c}{ Retained } & \multicolumn{2}{c}{ Conjugated } \\
\cline { 2 - 6 } \multicolumn{1}{c}{ Disorder } & \multicolumn{3}{c}{ Minutes af ter injection } \\
\cline { 2 - 6 } & 60 & 120 & 60 & 120 \\
\hline & $\%$ & $\%$ & $\%$ & $\%$ \\
Cirrhosis (12)* & 38 & 22 & 20 & 68 \\
Obstruction & 37 & 31 & 42 & 64 \\
Intrahepatic (6) & & & & \\
Extrahepatic (10) & & & & \\
\hline
\end{tabular}

* Number of subjects in parentheses; values reported are means.
Plaa, Sparkes, Abide, and Hunter (22), using an extraction procedure for the simultaneous estimation of free and conjugated BSP in the serum at 15,30 , and 45 minutes after a single intravenous injection of the dye, found four general types of abnormal patterns, but none was diagnostic for a specific type of hepatic disease. They found that "altered products of BSP" appeared quite rapidly and in high concentration during the first 15 minutes after BSP administra-

TABLE III

BSP transport in hepatic disorders

\begin{tabular}{lcccc}
\hline \hline \multicolumn{1}{c}{ Disorder } & PDR* & $\mathrm{Tm}$ & $\mathrm{S}$ & $\mathrm{S} / \mathrm{Tm}$ \\
\hline & $\begin{array}{c}\text { \%/ } \\
\text { minute }\end{array}$ & $\begin{array}{c}m g / \\
\text { minute }\end{array}$ & $\begin{array}{c}m g / m g / \\
100 \mathrm{ml} \\
\text { plasma }\end{array}$ & \\
Cirrhosis (12)† & 3.1 & 3.0 & 12.2 & 4.1 \\
Obstruction & 3.6 & 2.7 & 18.9 & 6.0 \\
$\quad$ Intrahepatic (6) & & & & \\
Extrahepatic (10) & & & &
\end{tabular}

* See Table I for abbreviations.

$\dagger$ Number of subjects in parentheses; values reported are means. 


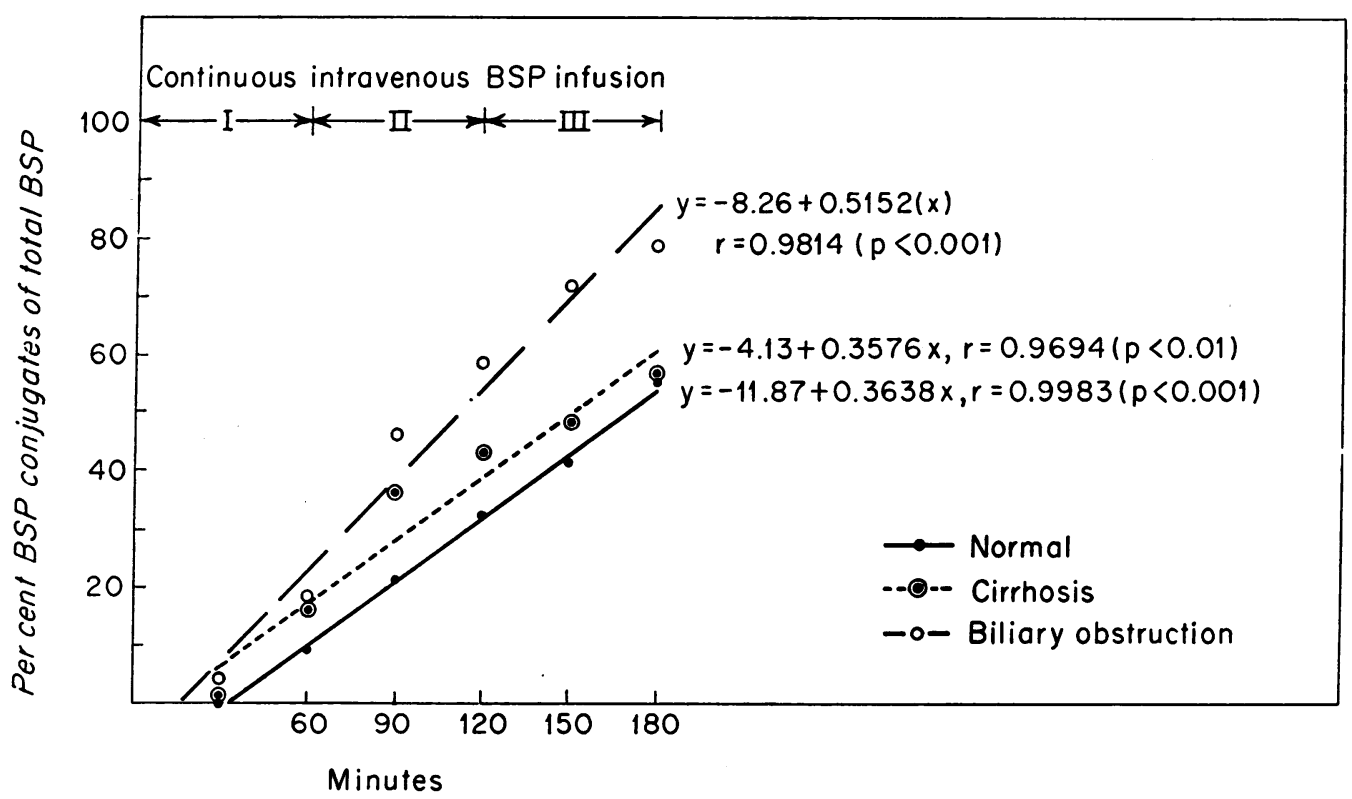

Fig. 2. Regression of mean percentage of conjugated BSP (among total Serum BSP) ON TIME DURING CONTINUOUS INTRAVENOUS INFUSION. Linear regression equations $(y=a+$ $b x)$, correlation coefficients $(\mathrm{r})$, and probabilities of chance occurrence for these correlations (p) are indicated on the graph. Points on the graph represent mean values for all determinations made at the indicated time in each group of subjects (without hepatic disorders, portal and postnecrotic cirrhosis, and biliary obstruction). Rates of infusion during first (I) and third (III) infusion periods were greater than theoretical $\mathrm{Tm}$; the rate during second period (II) was, in general, less than Tm.

tion in normal subjects (23). The authors stated that the identity and source of this early form of BSP was unknown and that it was not necessarily a conjugate of BSP. With the paper chromatographic technic we have not been able to identify measurable amounts of BSP metabo- lites at 5,10 , or 15 minutes after intravenous administration.

A decrease in PDR with normal 45-minute BSP retention noted in subjects with hemochromatosis has been observed previously by Mendenhall and Leevy (24). Diminution of $\mathrm{Tm}$ and $\mathrm{S}$ in

TABLE IV

Percentage BSP conjugates in total serum BSP during continuous intravenous infusion of BSP at three rates

\begin{tabular}{|c|c|c|c|c|c|c|c|}
\hline \multirow{2}{*}{$\begin{array}{c}\text { Infusion } \\
\text { period } \\
(60 \\
\text { minutes) }\end{array}$} & \multirow{2}{*}{$\begin{array}{l}\text { Minutes } \\
\text { of } \\
\text { infusion }\end{array}$} & \multicolumn{2}{|c|}{$\begin{array}{l}\text { Without hepatic } \\
\text { disorder* }\end{array}$} & \multicolumn{2}{|c|}{$\begin{array}{l}\text { Portal and postne- } \\
\text { crotic cirrhosis† }\end{array}$} & \multicolumn{2}{|c|}{$\begin{array}{l}\text { Obstruction (extra- } \\
\text { and intrahepatic) } \dagger\end{array}$} \\
\hline & & Mean & Range & Mean & Range & Mean & Range \\
\hline I & $\begin{array}{l}30 \\
60\end{array}$ & $\begin{array}{l}0 \\
9\end{array}$ & $\underset{5-16(9)}{0}$ & $16^{1.5}$ & $\begin{array}{c}0-6(4) \\
10-20(5)\end{array}$ & $\begin{array}{r}4 \\
18\end{array}$ & $\begin{array}{l}0-10(5) \\
9-28(6)\end{array}$ \\
\hline II & $\begin{array}{r}90 \\
120\end{array}$ & $\begin{array}{l}21 \\
32\end{array}$ & $\begin{array}{l}10-31(9) \\
26-40(9)\end{array}$ & $\begin{array}{l}36 \\
43\end{array}$ & $\begin{array}{l}28-43(5) \\
39-49(5)\end{array}$ & $\begin{array}{l}46 \\
58\end{array}$ & $\begin{array}{l}36-52(4) \\
50-64(5)\end{array}$ \\
\hline III & $\begin{array}{l}150 \\
180\end{array}$ & $\begin{array}{l}41 \\
55\end{array}$ & $\begin{array}{l}28-58(5) \\
45-68(5)\end{array}$ & $\begin{array}{l}48 \\
56\end{array}$ & $\begin{array}{l}34-59(4) \\
30-74(3)\end{array}$ & $\begin{array}{l}71 \\
78\end{array}$ & $\begin{array}{l}56-79(3) \\
62-84(3)\end{array}$ \\
\hline
\end{tabular}

* Infusion rates: I, $0.30 ; \mathrm{II}, 0.09 ; \mathrm{III}, 0.18 \mathrm{mg}$ per $\mathrm{kg}$ per minute.

$\dagger$ Infusion rates: I, 0.15 ; II, 0.045 ; III, $0.09 \mathrm{mg}$ per $\mathrm{kg}$ per minute.

$\ddagger$ The number of patients on which determinations were made is in parentheses. 
TABLE V

Parameters of BSP transport and metabolism in one patient during convalescence from infectious hepatitis

\begin{tabular}{|c|c|c|c|c|c|}
\hline & & & & me of te & \\
\hline Paramete & & & Initial & $\begin{array}{l}\text { At } 10 \\
\text { days }\end{array}$ & $\begin{array}{l}\text { At } 6 \\
\text { weeks }\end{array}$ \\
\hline $\begin{array}{l}\text { BSP retention } \\
\text { ( } 60 \text { minutes), \% }\end{array}$ & & & 28 & 16 & 3 \\
\hline $\begin{array}{l}\text { BSP conjugated } \\
(60 \text { minutes }), \%\end{array}$ & & & 24 & 26 & \\
\hline PDR, \%/minute & & & 4 & 5.6 & 12.4 \\
\hline $\mathrm{Tm}, m g / m i n u t e$ & & & 4.2 & 3.2 & 4.1 \\
\hline $\mathrm{S}, m g / m g / 100 m l p$ & ssma & & 21.8 & 34.4 & 50.0 \\
\hline $\mathrm{S} / \mathrm{Tm}$ & & & 5.2 & 10.8 & 12.2 \\
\hline $\begin{array}{l}\text { Conjugated serum } \\
\text { BSP during } \\
\text { continuous }\end{array}$ & $I^{*}$ & $\frac{30 \dagger}{60}$ & $\mathbf{0}$ & $\begin{array}{r}\mathbf{0} \\
\mathbf{1 3}\end{array}$ & $\begin{array}{r}0 \\
10\end{array}$ \\
\hline & & $\begin{array}{r}90 \\
120\end{array}$ & $\begin{array}{l}39 \\
48\end{array}$ & $\begin{array}{l}35 \\
41\end{array}$ & $\begin{array}{l}17 \\
28\end{array}$ \\
\hline & III & $\begin{array}{l}150 \\
180\end{array}$ & $\begin{array}{l}44 \\
59\end{array}$ & 48 & $\begin{array}{l}51 \\
56\end{array}$ \\
\hline
\end{tabular}

* Blood samples tested at half-hour intervals during 3 hours of continuous intravenous infusion of BSP at different rates (I, II, III). $\dagger$ Minutes of infusion.

our subjects with hepatic disease is similar to that found by Wheeler and co-workers (16). That a better discrimination between patients with portal or postnecrotic cirrhosis and those with biliary obstruction could not be achieved by these measurements emphasizes the importance of dysfunction at the cellular and subcellular levels in all hepatobiliary disease. A better preservation of $S$ values in patients with biliary obstruction might have been anticipated even though secondary hepatocellular damage at the ultramicroscopic (25) and enzymatic (26) levels is known to occur. The recent report of Preisig, Williams, Sweeting, and Bradley (27) seems to suggest that the $\mathrm{S} / \mathrm{Tm}$ ratio might offer better differentiation of these conditions. The overlap of S/Tm values between our cases of obstruction and of cirrhosis suggests that accurate differentiation cannot be expected on this basis.

Recently, Castenfors and Hultman (28) recommended injecting a large single dose of BSP (20 $\mathrm{mg}$ per $\mathrm{kg}$ ) intravenously so that theoretically the transport mechanism would be working at full capacity for 30 to 60 minutes. They suggested that such a technic is better than the 5-mg per $\mathrm{kg}$ dose for diagnosing mild liver disease and that by analysis of the blood disappearance curve an estimate of the Tm might be made without constant infusion.
We did not attempt to determire conjugating capacity under these circumstances.

Presumably the appearance of BSP conjugates in the serum during the course of constant infusion of the dye is a result of reflux from the liver to the bloodstream (29). The percentage of conjugates in the serum during the course of continuous infusion seemed to be as much a function of time as of the functional status of the liver. The rate of appearance was greatest in those patients with extrahepatic obstruction; this suggests that the highest rate as well as the largest amount of reflux occurs in this group. The rate of appearance of BSP conjugates in the serum during the 3-hour infusion was the same for the cirrhotic subgroup and for the group without hepatic disorders. The former, however, appeared to exhibit a larger reflux of conjugated BSP from the liver to the serum than normal during the first 2 hours, as suggested by the greater percentage of conjugated BSP in serum during the infusions in cirrhotic patients (Figure 2). The tendency to plateau during the third hour may suggest "fatigue" of the conjugating mechanisms in the cirrhotics.

Monroe and Kittinger (30) found that the biliary concentration of BSP metabolites in human T-tube bile was related to the functional status of the liver as well as to the time of bile sampling after a single intravenous injection of the dye. Wirts and Bradford (31) suggested that the excretion of BSP in bile collected by duodenal intubation after intravenous injection of BSP be utilized as a test of liver function. They found that a significant percentage of 25 patients convalescing from hepatitis with otherwise normal or equivocal results of liver function tests showed impaired liver function on the biliary BSP test. Preisig and co-workers (27) recently reported a more rapid return of $S$ than $T m$ toward normal values during the recovery phase of acute hepatitis. The finding of a depressed $\mathrm{Tm}$ in our patient with viral hepatitis when all other values of liver function tests had returned to normal supports the contention that biliary excretion of BSP may be one of the last functions to return to normal after a bout of hepatitis. It is interesting that when the Tm was depressed, the percentage of conjugated BSP in the serum during 
constant infusion was normal, in contrast to other instances of decreased $\mathrm{Tm}$ such as occur after biliary obstruction or intrahepatic cholestasis (32). Norberg, Senning, and William-Olsson (33) have proposed a concept of "reversible extraction" of BSP not necessarily by way of the lymph or enterohepatic circulation. They speculated upon a direct return of unconjugated BSP to the blood from the hepatic storage space, although they did suggest that reflux is partly in the form of metabolites.

\section{Summary}

BSP transport and metabolism have been studied in 33 persons with hepatic disorders and 19 without. Single injections and continuous infusions of BSP were administered intravenously, and measurements reflecting hepatic uptake, relative storage capacity, conjugation, and maximal biliary excretion of BSP were obtained. We suggest that such determinations contribute to understanding of the pathophysiologic phenomena involved in certain hepatic disorders.

Hepatic uptake, relative storage capacity, and maximal biliary excretion of BSP are diminished in most hepatobiliary diseases whether primarily hepatocellular or obstructive. This finding supports the impression that disturbances of function at the cellular and subcellular levels occur after extrahepatic bile-duct obstruction. None of these parameters of BSP metabolism distinguished between intrahepatic and extrahepatic obstruction.

Determination of retained BSP and BSP conjugates at both 60 and 120 minutes after a single injection of the dye may be helpful in differentiating cirrhosis from obstructive jaundice. In patients with cirrhosis, BSP retention declined more sharply between the first and second hours after injection than in patients with obstructive jaundice. The percentage of serum BSP present in conjugated form 1 hour after injection was significantly less in patients with cirrhosis than in those with obstruction. In these two groups of patients, the percentage of conjugated BSP in the serum at 120 minutes was approximately equal.

The appearance of conjugated BSP in the serum during continuous infusion of the dye is related to time as well as to the nature of the pathophysiologic process.

\section{Acknowledgment}

The invaluable technical assistance of Miss Synnove Johansen is acknowledged.

\section{References}

1. Rosenthal, S. M., and E. C. White. Clinical application of the bromsulphalein test for hepatic function. J. Amer. med. Ass. 1925, 84, 1112.

2. Mendeloff, A. I., P. Kramer, F. J. Ingelfinger, and S. E. Bradley. Studies with bromsulfalein. II. Factors altering its disappearance from the blood after a single intravenous injection. Gastroenterology 1949, 13, 222.

3. Combes, B., and G. S. Stakelum. A liver enzyme that conjugates sulfobromopththalein sodium with glutathione. J. clin. Invest. 1961, 40, 981.

4. Rosenau, W., J. V. Carbone, and G. M. Grodsky. Metabolism of sulfobromophthalein in hepatectomized and hepatectomized-nephrectomized dog. Proc. Soc. exp. Biol. (N. Y.) 1959, 102, 131.

5. Lorber, S. H., M. J. Oppenheimer, H. Shay, P. Lynch, and $H$. Siplet. Enterohepatic circulation of bromsulphalein: intraduodenal, intraportal and intravenous dye administration in dogs. Amer. J. Physiol. 1953, 173, 259.

6. Ingelfinger, F. J., S. E. Bradley, A. I. Mendeloff, and P. Kramer. Studies with bromsulfalein. I. Its disappearance from the blood after a single intravenous injection. Gastroenterology 1948, 11, 646.

7. Leevy, C. M. Dye extraction by the liver in Progress in Liver Diseases, H. Popper and F. Schaffner, Eds. New York, Grune \& Stratton, 1961, vol. 1, p. 174.

8. Barber-Riley, G., A. E. Goetzee, T. G. Richards, and J. Y. Thomson. The transfer of bromsulphthalein from the plasma to the bile in man: Clin. Sci. 1961, 20, 149.

9. Brauer, R. W., and R. L. Pessotti. Hepatic uptake and biliary excretion of bromsulphthalein in the dog. Amer. J. Physiol. 1950, 162, 565.

10. Combes, B. The biliary excretion of sulfobromophthalein sodium (BSP) in the rat as a conjugate of glycine and glutamic acid. J. clin. Invest. 1959, 38, 1426.

11. Grodsky, G. M., J. V. Carbone, and R. Fanska. Identification of metabolites of sulfobromophthalein. J. clin. Invest. 1959, 38, 1981.

12. Meltzer, J. I., H. O. Wheeler, and W. I. Cranston. Metabolism of sulfobromophthalein sodium (BSP) in dog and man. Proc. Soc. exp. Biol. (N. Y.) 1959, 100, 174.

13. Carbone, J. V., and G. M. Grodsky. Metabolism of sulfobromophthalein sodium (BSP): recent advances. Gastroenterology 1960, 38, 659.

14. Cantarow, A., C. W. Wirts, W. J. Snape, and L. L. Miller. Excretion of bilirubin and bromsulfalein in bile. Amer. J. Physiol. 1948, 154, 211. 
15. Bradley, S. E., F. J. Ingelfinger, G. P. Bradley, and J. J. Curry. The estimation of hepatic blood flow in man. J. clin. Invest. 1945, 24, 890.

16. Wheeler, H. O., J. I. Meltzer, and S. E. Bradley. Biliary transport and hepatic storage of sulfobromophthalein sodium in the unanesthetized dog, in normal man, and in patients with hepatic disease. J. clin. Invest. 1960, 39, 1131.

17. Schoenfield, L. J., D. B. McGill, and W. T. Foulk. Studies of sulfobromophthalein sodium (BSP) metabolism in man. III. Demonstration of a transport maximum ( $\mathrm{Tm}$ ) for biliary excretion of BSP. J. clin. Invest. 1964, 43, 1424.

18. Combes, B., H. O. Wheeler, A. W. Childs, and S. E. Bradley. The mechanisms of bromsulfalein removal from the blood. Trans. Ass. Amer. Phycns 1956, 64, 276.

19. Wheeler, H. O., R. M. Epstein, R. R. Robinson, and E. S. Snell. Hepatic storage and excretion of sulfobromophthalein sodium in the dog. $\mathrm{J}$. clin. Invest. 1960, 39, 236.

20. Carbone, J. V., G. M. Grodsky, and V. Hjelte. Effect of hepatic dysfunction on circulating levels of sulfobromophthalein and its metabolites. J. clin. Invest. 1959, 38, 1989.

21. Higgins, F. E., W. T. Foulk, and J. L. Bollman. Column chromatography of bile, serum, and urine after intravenous administration of sulfobromophthalein. Gastroenterology 1960, 38, 194.

22. Plaa, G. L., R. D. Sparks, J. K. Abide, and F. M. Hunter. Clinical usefulness of determining bromsulphalein and its metabolic products: preliminary observations. Sth. med. J. (Bgham, Ala.) 1961, 54, 1026.

23. Plaa, G. L., R. D. Sparks, and F. M. Hunter. A study on the appearance of altered sulfobromophthalein (BSP) in human serum. Gastroenterology $1962,42,678$.

24. Mendenhall, C. L., and C. M. Leevy. False-nega- tive bromsulfalein tests. New Engl. J. Med. 1961, 264, 431.

25. Schaffner, F., and H. Popper. Electron microscopic study of human cholestasis. Proc. Soc. exp. Biol. (N. Y.) 1959, 101, 777.

26. Schoenfield, L. J., J. L. Bollman, and H. N. Hoffman II. Sulfate and glucuronide conjugates of bilirubin in experimental liver injury. J. clin. Invest. 1962, 41, 133.

27. Preisig, R., R. Williams, J. Sweeting, and S. E. Bradley. Quantitative approach to the study of liver function in normal man, during the course of hepatitis and in other forms of liver disease (abstract). Gastroenterology 1963, 44, 479.

28. Castenfors, H., and E. Hultman. Elimination of single high doses of bromsulphalein (BSP) used as a test of liver function. Scand. J. clin. Lab. Invest. 1962, 14 (suppl. 64), 45.

29. Schoenfield, L. J., D. B. McGill, D. B. Hunton, W. T. Foulk, and H. R. Butt. Studies of chronic idiopathic jaundice (Dubin-Johnson syndrome). I. Demonstration of hepatic excretory defect. Gastroenterology 1963, 44, 101.

30. Monroe, L. S., and A. L. Kittinger. The biliary dynamics of the metabolites of sulfobromophthalein sodium (BSP) in man. J. Lab. clin. Med. 1961, 58, 468.

31. Wirts, C. W., Jr., and B. K. Bradford. The biliary excretion of bromsulfalein as a test of liver function in a group of patients following hepatitis or serum jaundice. J. clin. Invest. 1948, 27, 600.

32. Schoenfield, L. J., and W. T. Foulk. Studies of sulfobromophthalein sodium (BSP) metabolism in man. II. The effect of artificially induced fever, norethandrolone (Nilevar), and iopanoic acid (Telepaque). J. clin. Invest. 1964, 43, 1419.

33. Norberg, Bo, A. Senning, and G. William-Olsson. On the reversible extraction of bromsulfalein (BSP) in the liver. Acta physiol. scand. 1962, $55,26$. 